\title{
PERBANDINGAN KETERAMPILAN PROSES SAINS SISWA DENGAN MENGGUNAKAN MODEL PEMBELAJARAN PROBLEM BASED LEARNING (PBL) DAN PROJECT BASED LEARNING (PJBL) PADA MATERI KEANEKARAGAMAN HAYATI
}

\author{
Indah Pratiwi ${ }^{1 *}$, Ahmad Shafwan S. Pulungan ${ }^{2}$, Dumasari ${ }^{3}$ \\ 1,2Program Studi Pendidikan Biologi, FMIPA, Universitas Negeri Medan, JI. Willem Iskandar Psr. V Medan Estate, \\ Medan, Indonesia, 20221 \\ ${ }_{3}^{3}$ SMA Negeri 3 Kisaran, Jl. S. Parman, Kec. Kisaran Barat, Kabupaten Asahan, Sumatera Utara, Indonesia \\ *Korespondensi Author: pratiwwiindah@gmail.com
}

\section{INFOARTIKEL}

Histori Artikel

Received 17 Januari 2019

Revised 26 Maret 2020

Accepted 26 Maret 2020

Published 10 April 2020

Keywords:

Problem Based Learning, Project Based Learning, Science Process Skill

\begin{abstract}
ABSTRAK
Penelitian ini bertujuan untuk mengetahui perbandingan keterampilan proses sains siswa yang diajarkan dengan Problem Based Learning (PBL) dan Project Based Learning ( $\mathrm{PjBL}$ ) pada materi keanekaragaman hayati di kelas $\mathrm{X}$ SMA Negeri 3 Kisaran T.P 2018/2019. Populasi penelitian adalah siswa kelas X IPA SMA Negeri 3 Kisaran Tahun Pembelajaran 2018/2019. Sampel penelitian adalah siswa kelas X IPA 1 dan X IPA 2 yang ditentukan dengan teknik random sampling. Penelitian ini merupakan penelitian eksperimen semu dengan rancangan pretest-posttest group design. Data dikumpulkan dengan menggunakan tes keterampilan proses sains dan lembar observasi. Data kemudian dianalisis dengan uji-t pada taraf signifikansi 0,05. Berdasarkan analisis data diperoleh thitung $>$ ttabel $(4,81>2,01)$ yang artinya terdapat perbedaan signifikan keterampilan proses sains siswa kelas X SMA Negeri 3 Kisaran Tahun Pembelajaran 2018/2019 yang diajarkan dengan Problem Based Learning (PBL) dan Project Based Learning (PjBL). Hasil analisis tes keterampilan proses sains menunjukan rata-rata nilai keterampilan proses sains siswa yang diajarkan dengan model pembelajaran PBL mencapai 82,5 berkriteria sangat terampil sedangkan rata-rata nilai keterampilan proses sains siswa kelas PjBL mencapai 70,57 berkriteria terampil.
\end{abstract}

\section{ABSTRACT}

This research was aimed to know the difference of science process skill between students of SMA Negeri 3 Kisaran in the academic year of 2018/2019 which were taught by Problem Based Learning (PBL) and those taught by using Project Based Learning (PjBL) on diversity lesson. The population of this study is tenth grade students in SMA Negeri 3 Kisaran in academic year 2018/2019, then X IPA 1 and X IPA 2 were selected as sample of this study through simple random sampling technique. This study was quasi experimental research with pretest-posttest group design. Data were collected by science process skill test and observation, which then analyzed by t-test on 0.05 signification degree. Using t-test values obtained tcount> ttable $(4.81>2.01)$ it's means there are significant differences in science process skill of class $X$ Students of SMA Negeri 3 Kisaran in academic year 2018/2019 which were taught by PBL dan PjBL. Based on the result of analysis of the average score of science process skill test, student' science process skills were thaught by PBL achieve 82,5 with pretty good criteria and student' science process skills were thaught by PjBL achieve 70,57 with good criteria.

Copyright (C) 2019 Universitas Negeri Medan. Artikel Open Access dibawah lisensi CCBY-4.0 (https://creativecommons.org/licenses/by/4.0) 
How To Cite:

Pratiwi, I., Pulungan, A.S.S., \& Dumasari. (2020). Perbandingan Keterampilan Proses Sains Siswa dengan Menggunakan Model Pembelajaran Problem Based Learning (PBL) dan Project Based Learning (PjBL) Pada Materi Keanekaragaman Hayati. Jurnal Pelita Pendidikan, 8(1), 062-070.

\section{PENDAHULUAN}

Sesuai peraturan Menteri Pendidikan dan Kebudayaan Republik Indonesia No. 81A Tahun 2013 tentang implementasi kurikulum, maka satuan pendidikan di Indonesia secara bertahap menerapkan kurikulum 2013. Salah satu esensi dari kurikulum 2013 adalah penerapan pendekatan pembelajaran scientific. Pada pendekatan ini, proses pembelajaran dirancang sedemikian rupa agar peserta didik secara aktif mengkonstruksi konsep, hukum atau prinsip melalui tahapantahapan mengamati, menanya, mengumpulkan informasi, menalar dan mengkomunikasikan konsep, hukum, atau prinsip yang ditemukan (Umar, 2017). Sesuai dengan pernyataan tersebut maka kurikulum 2013 menuntut penggunaan model pembelajaran yang bisa mengembangkan kemampuan siswa khususnya keterampilan proses siswa. Keterampilan proses terbagi menjadi dua yaitu keterampilan dasar (basic skill) dan keterampilan terintegrasi (integrated skill). Keterampilan dasar terdiri dari enam keterampilan yaitu mengamati, mengukur, mengklasifikasi, mengkomunikasi, menyimpulkan dan memprediksi. Ke-enam keterampilan proses sains ini dipandang penting dan harus dikuasai oleh siswa, karena keterampilan-keterampilan ini merupakan landasan untuk menerapkan metode-metode ilmiah dan keterampilan terintegritas lainnya (Dewi, 2009).

Berdasarkan survei yang dilakukan oleh Program for International Student Assesment (PISA), rata-rata skor literasi sains siswa Indonesia adalah 403 dan berada di peringkat 62 dari 70 negara (PISA, 2015). Skor literasi sains siswa Indonesia ini masih dibawah rata-rata skor OECD (Organisation for Economis Co-operation and Development), dimana skor rata-rata OECD adalah 493. Terdapat tiga kompetensi ilmiah yang diukur dalam literasi sains berdasarkan konsep literasi sains yang didefenisikan PISA yaitu: (a) menjelaskan fenomena ilmiah: menerapkan ilmu pengetahuan dalam situasi tertentu, menggambarkan atau menafsirkan fenomena ilmiah dan memprediksi perubahan, mengidentifikasi deskripsi yang tepat, memberikan penjelasan, dan prediksi; (b) mengevaluasi dan merancang penyelidikan ilmiah: mengenali masalah yang mungkin untuk penyelidikan ilmiah, mengidentifikasi kata kunci untuk mencari informasi ilmiah, mengenali fitur kunci dari penyelidikan ilmiah; (c) menggunakan bukti ilmiah: menafsirkan bukti ilmiah dan membuat kesimpulan dan mengkomunikasikan, mengidentifikasi asumsi, bukti, dan alasan di balik kesimpulan, berkaca pada implikasi sosial dari ilmu pengetahuan dan perkembangan teknologi (Odja dan Payu, 2014). Maka berdasarkan pernyataan tersebut, skor literasi sains siswa Indonesia juga dapat menunjukkan rendahnya tingkat keterampilan proses sains siswa Indonesia. Berbagai keterampilan sains seperti keterampilan mengamati sumber permasalahan, memprediksi perubahan dan fenomena ilmiah, menarik kesimpulan dan komunikasi dinilai masih kurang dikuasai siswa Indonesia.

Peningkatan keterampilan proses sains siswa bisa dilakukan oleh guru dengan menerapkan model pembelajaran yang tepat. Berdasarkan penelitian yang dilakukan oleh Nur et al. (2016) menunjukan bahwa pembelajaran berbasis masalah dapat meningkatkan keterampilan proses sains karena pembelajaran ini menyajikan pembelajaran yang aktif dan inovatif serta menuntut pengaplikasian keterampilan proses sains siswa. Selain pembelajaran berbasis masalah, pembelajaran berbasis proyek atau Project Based Learning ( $\mathrm{PjBL}$ ) juga dinilai bisa meningkatkan keterampilan proses sains siswa. Menurut Maghfiroh et al. (2016), model pembelajaran PjBL memiliki potensi untuk membantu siswa dalam proses pembelajaran serta mengembangkan kemampuan siswa dalam berbagai aspek termasuk keterampilan proses sains.

Materi kenekaragaman hayati sangat berkaitan dengan peristiwa alam sekitar. Materi ini mengajak siswa untuk memahami kompleksitas keanekaragaman makhluk hidup dan pentingnya peran setiap makhluk hidup di lingkungannya. Pembelajaran berbasis proyek menekankan pada 
kegiatan yang kompleks dan nyata, pembelajaran ini dapat menarik perhatian siswa dan meransang pemikiran kreatif siswa. Siswa dapat membuat proyek terkait permasalahan keanekaragamn hayati di sekitar mereka (Muktisari et al., 2016). Materi keanekaragaman hayati mengandung masalah-masalah nyata dalam kehidupan (autentik) dan bersifat illstructured problem, maka pembelajaran berbasis masalah juga dapat diterapkan pada materi ini. Kegiatan belajar berbasis masalah dapat menuntut dan meransang siswa untuk menggunakan kemampuan berpikir dan keterampilannya guna memecahkan masalah (Widayati et al., 2015).

SMA Negeri 3 Kisaran merupakan sekolah menengah atas yang terletak di kota Kisaran kabupaten Asahan, Sumatera Utara. Berdasarkan hasil wawancara dengan guru, kegiatan belajar yang dilakukan oleh guru biologi biasanya mengajarkan materi keanekaragaman hayati melalui ceramah, diskusi, dan penggunaan media gambar. Guru biologi belum pernah secara khusus menilai atau mengukur keterampilan proses sains siswa, namun menurut guru biologi keterampilan proses sains siswanya masih kurang maksimal. Dari permasalahan diatas maka peneliti ingin memberikan saran kepada guru biologi untuk menggunakan model pembelajaran berbasis masalah atau berbasis proyek untuk meningkatkan keterampilan proses sains siswa pada materi keanekaragaman hayati. Untuk melihat model pembelajaran mana yang paling efektif meningkatkan keterampilan proses sains siswa maka perlu untuk melakukan penelitian tentang Perbandingan Keterampilan Proses Sains Siswa dengan Menggunakan Model Pembelajaran Problem Based Learning (PBL) dan Project Based Learning ( $\mathrm{PjBL}$ ) pada Materi Keanekaragaman Hayati di Kelas X SMA Negeri 3 Kisaran T.P. 2018/2019. Penelitian ini bertujuan untuk mengetahui perbedaan keterampilan proses sains siswa yang diajarkan dengan model PBL dan PjBL pada materi keanekaragaman hayati di kelas X SMA Negeri 3 Kisaran T.P 2018/2019.

\section{METODE PENELITIAN}

Penelitian ini dilaksanakan di SMA Negeri 3 Kisaran yang beralamat di Jln. W. R. Supratman Kabupaten Asahan. Penelitian ini dilaksanakan pada
Agustus 2018 sampai dengan November 2018. Populasi dalam penelitian ini adalah seluruh siswa kelas X IPA yang terdiri dari 4 kelas yaitu 140 siswa. Pengambilan sampel dilakukan dengan teknik random sampling. Sampel penelitian sebanyak 2 kelas yaitu kelas X IPA 1 sebanyak 33 orang siswa dibelajarkan dengan model pembelajaran $\mathrm{PBL}$ dan kelas X IPA 2 sebanyak 36 siswa dibelajarkan dengan model pembelajaran PjBL.

Penelitian ini merupakan penelitian eksperimen semu (quasi eksperimental research) dengan rancangan penelitian berupa pretest posttest group design. Variabel bebas dalam penelitian ini adalah model pembelajaran Problem Based Learning (PBL) dan Project Based Learning $(\mathrm{PjBL})$. Variabel terikat dalam penelitian ini adalah keterampilan proses sains siswa.

Teknik pengumpulan data berupa tes dan observasi. Tes digunakan untuk mengukur kemampuan keterampilan proses sains siswa. Tes terdiri dari 20 butir soal yaitu 3 soal mewakili keterampilan mengamati, 6 soal mewakili keterampilan mengklasifikasi, 5 soal mewakili keterampilan mengkomunikasi, 2 soal mewakili keterampilan mengukur, 3 soal mewakili keterampilan memprediksi, dan 1 soal mewakili keterampilan menyimpulkan. Observasi digunakan selama berlangsungnya proses pembelajaran yang bertujuan untuk melihat keterampilan proses sains siswa selama proses pembelajaran.

Teknik analisis data awal yaitu melakukan melakukan uji validitas, reliabilitas, taraf kesukaran, dan daya pembeda soal. Uji prasyarat analisis meliputi uji normalitas dan homogenitas data. Teknik analisis data akhir yaitu menghitung skor keterampilan proses sains serta melakukan uji hipotesis menggunakan uji t pada taraf signifikansi 0,05 .

\section{HASIL DAN PEMBAHASAN}

Tes keterampilan proses sains dilakukan 2 dilakukan dua kali, yaitu sebelum eksperimen (pretest) dan sesudah eksperimen (posttest). Pretest pada kelas PBL diperoleh rata-rata nilai 49,3 dengan standar deviasi 12,23 dan sebaran normal atau Lo $<$ tabel $\left(\mathrm{L}_{0}=0,11 ; \mathrm{L}_{\text {tabel }}=0,15\right)$. Pretest keterampilan proses sains pada kelas PjBL diperoleh rata-rata nilai 46 dengan standar deviasi 9,63 dan sebaran normal atau $L_{0}<L_{\text {tabel }}\left(L_{0}=0,97 ; L_{\text {tabe }}=0,15\right)$. Perbandingan nilai pretest keterampilan proses sains siswa kedua kelas disajikan pada Gambar 1. 


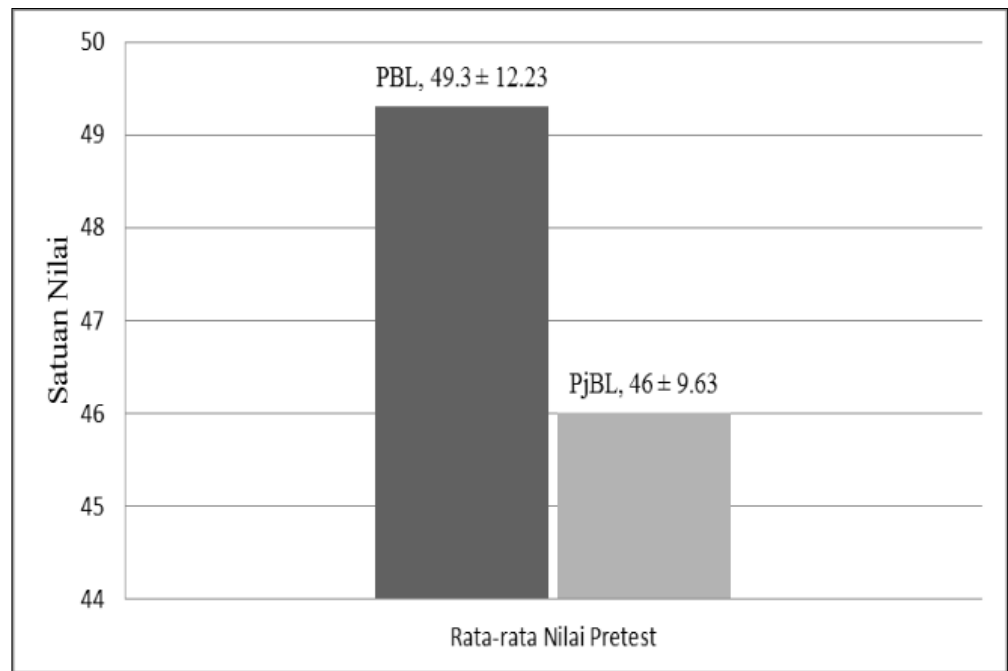

Gambar 1. Histogram Perbandingan Pretest Keterampilan Proses Sains Siswa Sebelum Dibelajarkan Menggunakan PBL (Rata-rata Nilai 49,3 dengan Standar Deviasi 12,23) dan PjBL Rata-rata Nilai 46 dengan Standar Deviasi 9,63)

Dari posttest keterampilan proses sains siswa kelas PBL diperoleh rata-rata nilai 82,5 dengan standar deviasi 8,83 dan sebaran normal atau Lo< Ltabel (Lo=0,09; Ltabel=0,15). Posttest keterampilan proses sains pada kelas PjBL diperoleh rata-rata nilai 70,57 dengan standar deviasi 12,62 dan sebaran normal atau Lo $<$ tabel $\quad\left(L_{0}=0,07\right.$; $\left.L_{\text {tabel }}=0,15\right)$. Perbandingan nilai posttest keterampilan proses sains siswa kedua kelas disajikan pada Gambar 2.

Hasil pretest keterampilan proses sains siswa kelas PBL dan PjBL selanjutnya dikategorikan menjadi 4 tingkat penguasaan keterampilan proses sains. Diagram tingkat penguasaan keterampilan proses sains siswa sebelum dibelajarkan dengan PBL dan PjBL disajikan pada Gambar 3.

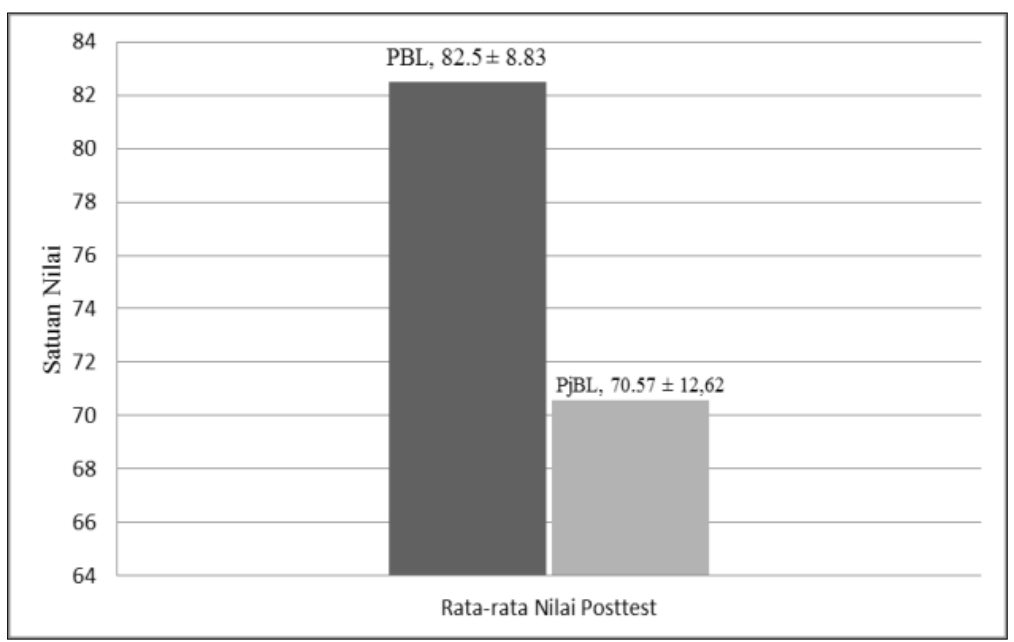

Gambar 2. Histogram Perbandingan Posttest Keterampilan Proses Sains Siswa Setelah Dibelajarkan Menggunakan PBL (Rata-rata Nilai 82,5 dengan Standar Deviasi 8,83) dan PjBL (Rata-rata Nilai 70,57 dengan Standar Deviasi 12,62) 
Pretest Keterampilan Proses Sains Siswa Kelas PBL

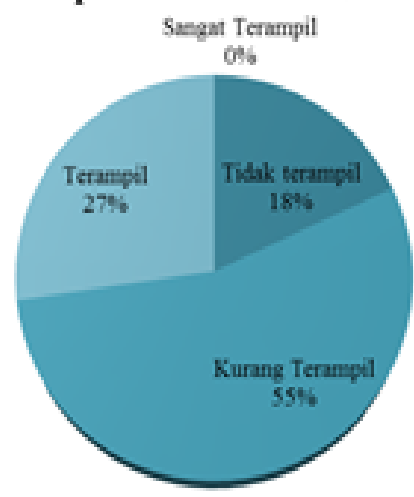

Gambar 3 Diagram Penguasaan Keterampilan Proses Sains Siswa Sebelum Dibelajarkan Menggunakan Model Pembelajaran PBL dan PjBL

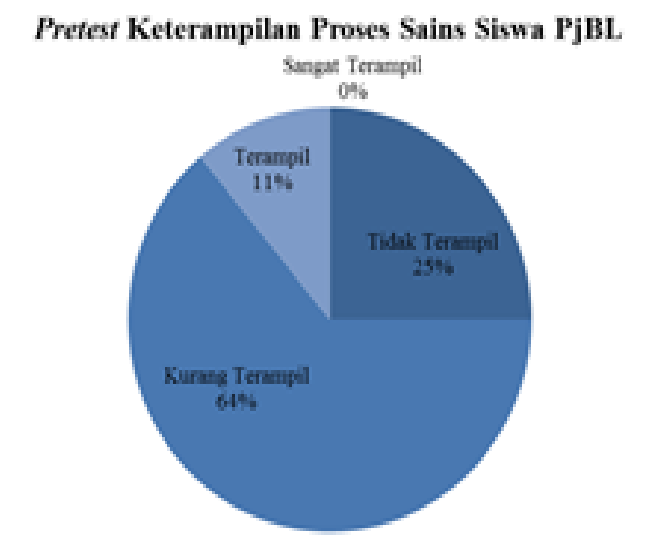

Gambar 3 menunjukkan bahwa sebelum dibelajarkan dengan model pembelajaran PBL sebanyak $18 \%$ siswa tidak terampil menggunakan keterampilan proses sains, 55\% siswa masih kurang terampil menggunakan keterampilan proses sains, $27 \%$ siswa terampil menggunakan keterampilan proses sains dan tidak ada siswa yang sangat terampil menggunakan keterampilan proses sains. Sebelum dibelajarkan dengan model pembelajaran PjBL sebanyak 25\% siswa tidak terampil menggunakan keterampilan proses sains, $64 \%$

\section{Posttest Keterampilan Proses Sains Siswa PBL}

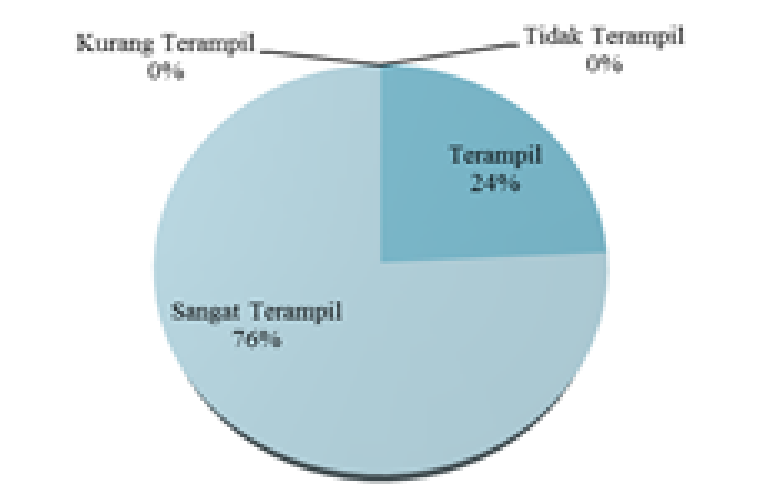

siswa masih kurang terampil menggunakan keterampilan proses sains, $11 \%$ siswa terampil menggunakan keterampilan proses sains dan tidak ada siswa yang sangat terampil menggunakan keterampilan proses sains.

Hasil posttest keterampilan proses sains siswa selanjutnya juga dikategorikan menjdi 4 tingkat penguasaan keterampilan proses sains. Diagram keterampilan proses sains siswa setelah dibelajarkan dengan model pembelajaran PBL dan PjBL disajikan pada Gambar 4.

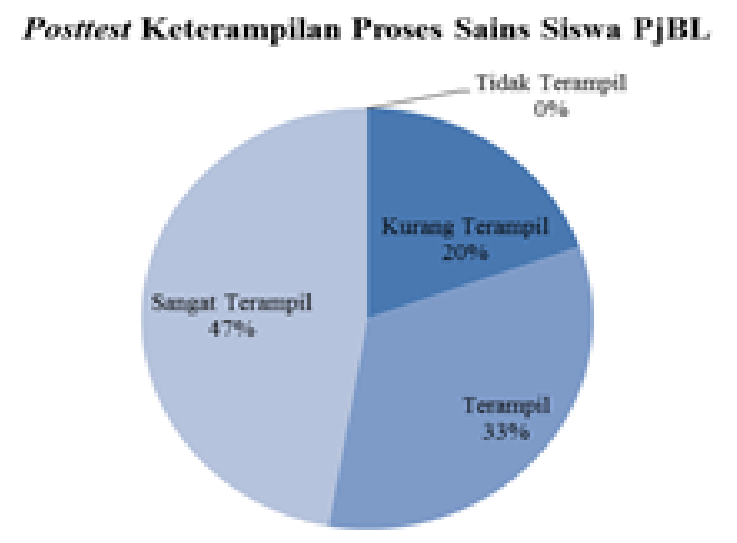

Gambar 4. Diagram Penguasaan Keterampilan Proses Sains Siswa Setelah Dibelajarkan Menggunakan Model Pembelajaran PBL dan PjBL

Gambar 4 menunjukkan bahwa setelah dibelajarkan dengan model pembelajaran PBL sebanyak $24 \%$ siswa telah terampil menggunakan keterampilan proses sains, $76 \%$ siswa sangat terampil menggunakan keterampilan proses sains, dan tidak ada siswa yang kurang dan tidak terampil menggunakan keterampilan proses sains. Setelah dibelajarkan dengan model pembelajaran PjBL sebanyak $20 \%$ siswa kurang terampil menggunakan keterampilan proses sains, 33\% siswa telah terampil menggunakan keterampilan proses sains, $47 \%$ siswa sangat terampil menggunakan keterampilan proses sains siswa dan tidak ada siswa yang tidak terampil menggunakan keterampilan proses sains.

Lembar observasi juga digunakan untuk melihat keterampilan proses sains siswa di kedua kelas eksperimen selama pembelajaran berlangsung. Perbandingan keterampilan proses sains siswa berdasarkan hasil observasi selama siswa dibelajarkan dengan menggunakan model pembelajaran PBL dan PjBL disajikan pada Gambar 5 dan Gambar 6. 


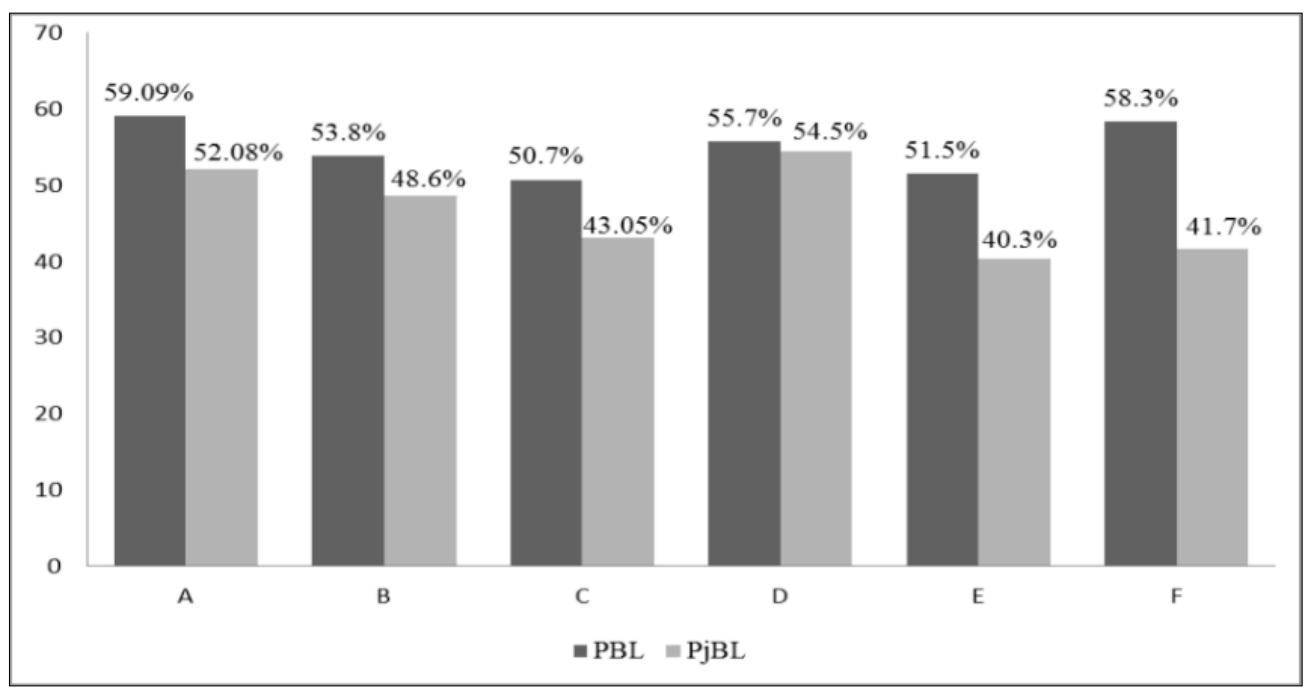

Gambar 5. Histogram Perbandingan Keterampilan Proses Sains (A) Mengamati, (B) Mengklasifikasi, (C) Mengkomunikasi, (D) Mengukur, (E) Memprediksi, (F) Menyimpulkan di Kelas PBL dan Kelas PjBL pada Pertemuan I

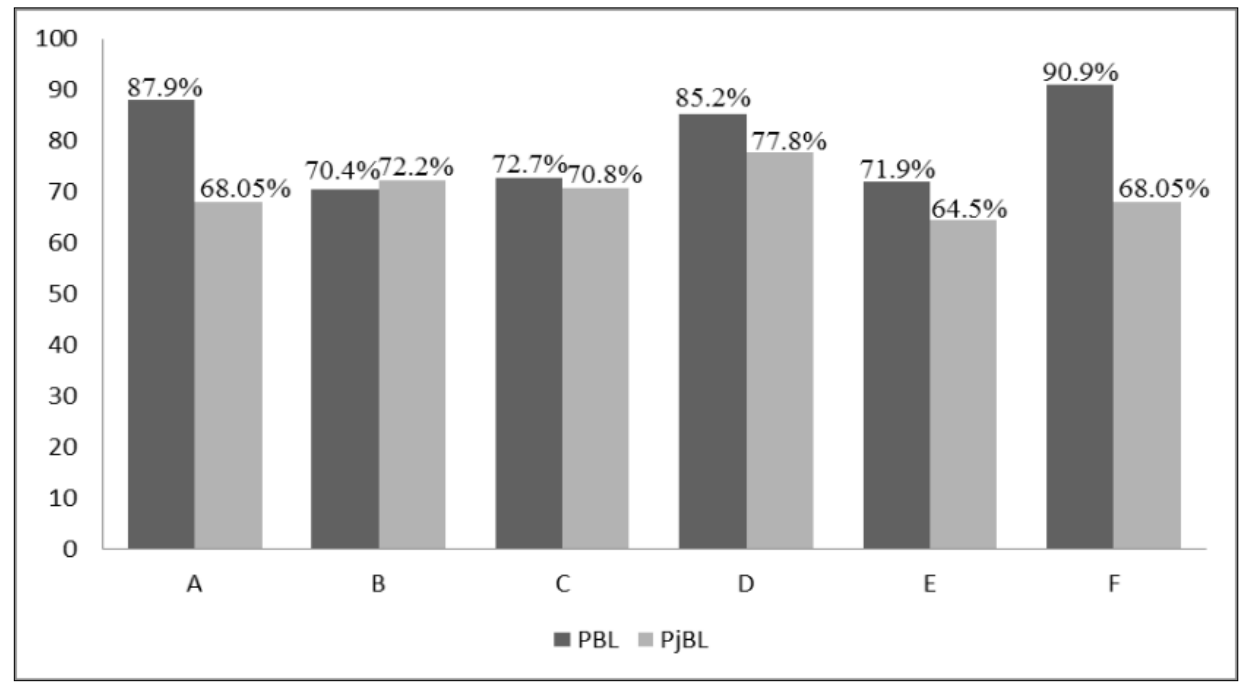

Gambar 6. Histogram Perbandingan Keterampilan Proses Sains (A) Mengamati, (B) Mengklasifikasi, (C) Mengkomunikasi, (D) Mengukur, (E) Memprediksi, (F) Menyimpulkan di Kelas PBL dan Kelas PjBL pada Pertemuan II

Gambar 5 dan 6 menunjukan perbandingan keterampilan proses sains perindikator selama siswa dibelajarkan dengan PBL dan PjBL pada pertemuan pertama dan kedua. Pada pertemuan pertama tampak bahwa seluruh indikator keterampilan proses sains siswa yang dibelajarkan dengan PBL lebih tinggi dibandingkan dengan siswa kelas PjBL. Pada pertemuan kedua tampak bahwa hampir seluruh indikator keterampilan proses sains siswa yang dibelajarkan dengan PBL lebih tinggi dibandingkan dengan siswa kelas PjBL kecuali pada indikator mengkomunikasi.

Berdasarkan hasil pengujian hipotesis dengan uji-t pada taraf signifikansi 0,05 terhadap rata-rata nilai posttest dari kedua kelompok penelitian diperoleh hasil $t_{\text {hitung }}=4,81$ dan $t_{\text {tabel }}=2,21$ maka diketahui $t_{\text {hitung }}>\mathrm{t}_{\text {tabel }}$ yang berarti Ha diterima atau terdapat perbedaan signifikan keterampilan proses sains siswa yang diajarkan dengan menggunakan model pembelajaran PBL dengan PjBL pada materi Keanekaragaman Hayati Kelas $X$ SMA Negeri 3 Kisaran Tahun Pembelajaran 2018/2019. Hasil pengujian menunjukan bahwa pembelajaran dengan menerapkan model pembelajaran PBL lebih efektif meningkatkan keterampilan proses sains siswa pada materi Keanekaragaman Hayati dibandingkan model pembelajaran $\mathrm{PjBL}$, hal ini terlihat dari perbedaan 
rata-rata nilai posttest keterampilan proses sains dimana rata-rata nilai siswa yang dibelajarkan dengan model pembelajaran PBL lebih tinggi dibandingkan kelompok siswa yang dibelajarkan dengan model pembelajaran PjBL $(82,5>70,57)$.

PBL sendiri merupakan pembelajaran yang berpusat pada pembelajar dimana peserta didik dapat mengadakan pengamatan, mengintegrasi antara teori, praktek, dan aplikasi atau penerapan pengetahuan serta pengembangan keterampilan (Hadi, 2017). Pembelajaran yang berpusat pada siswa menuntut siswa untuk aktif dan inovatif mengkonstruksi konsep pembelajaran. PBL merupakan pembelajaran yang mengaitkan antara pengalaman dalam kehidupan nyata dengan materi yang diajarkan, sehingga siswa dapat mencapai semua aspek dalam taksonomi Bloom (Ginting et al., 2017).

PBL memiliki serangkaian aktifitas pembelajaran yang menekankan pada proses penyelesaian masalah secara ilmiah. PBL dapat meningkatkan keterampilan proses sains siswa karena model pembelajaran ini dapat mengakomodasi keterampilan proses sains melalui penerapan sintaks pembelajarannya (Husen et al, 2017; Sari, 2016; Wahyudi et al, 2015). Langkahlangkah pembelajaran berbasis masalah membantu siswa melakukan metode ilmiah yang didalamnya terdapat keterampilan proses sains. Jika ditinjau dari langkah pertama yaitu orientasi masalah, siswa belajar tentang bagaimana permasalahan tersebut terjadi, apa yang menyebabkan permasalahan tersebut terjadi, dan siapa yang terlibat dalam permasalahan tersebut. Dengan kata lain, siswa melakukan pengamatan/observasi, yang merupakan bagian dari keterampilan proses sains, sebagai langkah awal melaksanakan pembelajaran. Mengingat pembelajaran berbasis masalah merupakan pembelajaran yang menerapkan metode ilmiah mulai dari orientasi masalah, penyelidikan/penelitian hingga penarikan kesimpulan maka keterampilan proses sains lainnya juga akan terlatih melalui penerapan pembelajaran ini (Sari, 2016).

Pernyataan diatas sesuai dengan pengamatan peneliti saat penerapan PBL di kelas eksperimen, siswa tampak menggunakan keterampilan proses sains mereka untuk bisa menyelesaikan permasalahan yang dikemukakan pada LKPD. Topik permasalahan yang menjadi materi pembelajaran adalah permasalahan keanekaragaman hayati yaitu dampak alih fungsi hutan menjadi lahan perkebunan dan flora fauna khas Sumatera Utara yang terancam punah. Siswa tampak menggunakan keterampilan mengamati untuk mengobservasi gambar dan video animasi serta cuplikan berita tentang pengrusakan hutan dan perburuan hewan serta dampak pengubahan fungsi hutan menjadi lahan perkebunan kelapa sawit. Siswa menggunakan keterampilan mengklasifikasi untuk mengelompokkan faktor penyebab dan dampak alih fungsi hutan menjadi lahan perkebunan sawit dan perburuan hewan sesuai dengan video dan gambar yang mereka lihat. Sebelum melakukan penyelidikan, siswa terlebih dahulu diminta untuk membuat hipotesis tentang dampak alih fungsi hutan menjadi lahan perkebunan kelapa sawit dan upaya yang bisa dilakukan untuk menanggulangi dampak yang ditimbulkan. Untuk melakukan penyelidikan siswa tampak mengumpulkan data dan informasi dari berbagai sumber seperti buku, artikel, dan internet. Keterampilan mengukur tampak pada kegiatan ini, siswa menggunakan keterampilan ini untuk memperoleh data berupa angka seperti luas hutan yang rusak, luas perkebunan kelapa sawit, jumlah produksi kelapa sawit beberapa tahun terakhir, serta data populasi flora fauna khas Sumatera Utara beberapa tahun terakhir.

Setelah memperoleh data, siswa kemudian membuat laporan yang berisi perbandingan luas hutan dan luas perkebunan kelapa sawit, jumlah produksi kelapa sawit dan produk berbahan sawit yang digunakan manusia, dampak negatif alih fungi hutan menjadi lahan perkebunan serta usulan upaya yang dapat dilakukan untuk menanggulangi atau mengurangi dampak yang di timbulkan. Pada topik flora dan fauna khas Sumatera Utara yang terancam punah siswa membuat laporan yang berisi penyebab kelangkaan flora fauna khas Sumatera Utara, keunikan flora fauna khas Sumatera Utara, upaya yang dapat dilakukan untuk menyelamatkan flora fauna tersebut. Siswa selanjutnya menyimpulkan faktor penyebab alih fungsi hutan menjadi lahan perkebunan, dampak negatif yang ditimbulkan dan upaya yang bisa dilakukan untuk menanggulangi dampak tersebut. Keterampilan proses sains yang tampak pada kegiatan ini ialah keterampilan menyimpulkan. Setelah selesai membuat laporan, siswa kemudian mempresentasikan hasil diskusi kelompoknya di depan kelas. Pada kegiatan ini, siswa tampak menggunakan keterampilan berkomunikasi untuk menyampaikan hasil penyelidikan yang telah mereka lakukan.

Pada penelitian ini, keterampilan proses sains siswa yang dibelajarkan dengan PjBL lebih rendah jika dibandingkan dengan siswa yang dibelajarkan dengan PBL. Siswa kelas PjBL saat mempelajari topik keanekaragaman hayati membuat produk berupa poster edukasi tentang ajakan melestarikan hutan dan album tentang flora fauna khas Sumatera Utara. Tahapan pembelajaran PjBL juga menekankan penyelesaian masalah secara 
ilmiah, sama halnya seperti PBL. Siswa dituntut untuk aktif dan inovatif menciptakan sebuah produk sebagai alternatif pemecahan masalah. Melalui tahapan PjBL inilah keterampilan proses sains siswa dapat dilatih sehingga keterampilan mereka kian meningkat. Namun dalam penelitian ini, PjBL kurang efektif dalam meningkatkan keterampilan proses sains siswa dibandingkan PBL. Berdasarkan hasil observasi selama pembelajaran berlangsung juga menunjukkan seluruh indikator keterampilan proses sains siswa kelas PjBL lebih rendah dibandingkan kelas $\mathrm{PBL}$ baik pada pertemuan I (Gambar 5) dan pertemuan II (Gambar $6)$.

Kurang efektifnya PjBL untuk meningkatkan keterampilan proses sains siswa dikarenakan adanya kendala dalam penerapan PjBL saat penelitian, seperti kurangnya waktu bagi siswa untuk bisa menyelesaikan seluruh tahapan pembelajaran dan penyelesaian proyek. Proyek yang dibuat siswa harus diselesaikan diluar jam sekolah sehingga guru tidak bisa mengamati secara langsung aktivitas dan pekerjaan siswa. Hal serupa juga diungkapkan oleh Yennita, et al (2015) bahwa sebanyak $50 \%$ guru setuju bahwa terbatasnya waktu mengerjakan proyek menjadi kendala pada proses pembelajaran, selain dibutuhkannya alat bantu dan biaya pembuatan proyek yang relatif mahal. Selain itu juga diperlukan pengetahuan dan keterampilan guru dalam mencari topik/tema proyek yang akan dilaksanakan seperti membuat panduan pelaksanaan proyek, memilih proyek yang sederhana dengan biaya murah dan tidak menggunakan banyak waktu dalam pembelajaran sehingga penerapan PjBL lebih efektif dan dapat memperoleh berbagai keunggulan melalui penerapan model pembelajaran ini.

Namun apabila dilihat dari hasil pretest dan posttest keterampilan proses sains siswa kelas PBL dan PjBL sama-sama menunjukan peningkatan. Sebelum dibelajarkan dengan PBL rata-rata nilai keterampilan proses sains siswa adalah 49,3 dengan kategori kurang terampil, setelah dibelajarkan dengan PBL keterampilan proses sains siswa meningkat menjadi 82,5 dengan kategori sangat terampil. Sebelum dibelajarkan dengan $\mathrm{PjBL}$ ratarata nilai keterampilan proses sains siswa adalah 46 dengan kategori kurang terampil, setelah dibelajarkan dengan PjBL keterampilan proses sains siswa meningkat menjadi 70,57 dengan kategori terampil. Setelah dibelajarkan dengan PBL dan PjBL tidak ada siswa yang tidak terampil menggunakan keterampilan proses sains. Penerapan PBL dan PjBL untuk meningkatkan keterampilan proses sains siswa pada penelitian ini sesuai dengan konsep teori belajar konstruktivisme, dimana kegiatan pembelajaran menuntut siswa untuk berperan aktif membangun sendiri pengetahuannya melalui pemecahan masalah autentik dari realitas lapangan. Kegiatan pembelajaran seperti ini dapat meningkatkan pemahaman dan keterampilan siswa melalui proses menyelesaikan konsep dan ide-ide baru dengan kerangka berpikir yang telah ada dan dimiliki siswa (Rusman, 2010).

\section{KESIMPULAN}

Keterampilan proses sains siswa kelas $\mathrm{X}$ SMA Negeri 3 Kisaran Tahun Pembelajaran 2018/2019 yang diajarkan dengan model pembelajaran Problem Based Learning meningkat dari kategori kurang terampil $(49.3 \pm 12.23)$ menjadi kategori sangat terampil $(82,5 \pm 8.83)$. Keterampilan proses sains siswa kelas X SMA Negeri 3 Kisaran Tahun Pembelajaran 2018/2019 yang diajarkan dengan model pembelajaran Project Based Learning meningkat dari kategori kurang terampil (46 \pm 9.63$)$ menjadi kategori terampil $(70,57 \pm 12,62)$. Terdapat perbedaan yang signifikan keterampilan proses sains siswa kelas X SMA Negeri 3 Kisaran Tahun Pembelajaran 2018/2019 yang diajarkan dengan Problem Based Learning (PBL) dan Project Based Learning (PjBL).

\section{DAFTAR PUTAKA}

Dewi, S. (2009). Keterampilan Proses Sains. Bogor: CV Regina.

Ginting, I. D., E. Djulia, dan T. Gultom. (2017). Pengaruh Strategi Pembelajaran Problem Based Learning (PBL) dan Group Investigation (GI) Terhadap Keterampilan Proses Sains di MAN Kabanjahe. Jurnal Pendidikan Biologi, 6(3), 381-386.

Hadi, K. (2017). Pengembangan Model Problem Based Learning Berbasis Kearifan Lokal pada Materi Keanekaragaman Hayati Kelas X di Kabupaten Aceh Selatan. BIOnatural, 4(2), 42-52.

Husen, A., Indriwati, S. E. dan Lestari, U. (2017). Peningkatan Kemampuan Berpikir Kritis dan Keterampilan Proses Sains SMA Melalui Implemantasi Problem Based Learning Dipadu Think Pair Share. Jurnal Pendidikan: Teori, Penelitian, dan Pengembangan, 2(6), 853-860.

Maghfiroh, N., H. Susilo, dan A. Gofur. (2016). Pengaruh Project Based Learning terhadap Keterampilan Proses Sains Siswa Kelas $X$ SMA Negeri Sidoarjo. Jurnal Pendidikan Biologi Pascasarjana Universitas Negeri Malang, 1(8), 1588-1593.

Muktisari, E., M. Rahayuningsih, dan A. Irsadi. (2016). Efektifitas Model Pembelajaran Project Based Learning dengan Media 
Fotonovela Keanekaragaman Hayati terhadap Kemampuan Psikomotorik Siswa. Unnes Science Education Journal, 5(3), 14461450.

Nur, S., I. P. Pujiastuti, dan S. R. Rahman. (2016). Efektivitas Model Problem Based Learning (PBL) terhadap Hasil Belajar Mahasiswa Prodi Pendidikan Biologi Universitas Sulawesi Barat. Jurnal SaintifiK, 2(2), 133141.

Odja, A. H. dan C. S. Payu. (2014). Analisis Kemampuan Awal Literasi Sains Siswa Pada Konsep IPA. Prosiding Seminar Nasional Kimia (hal. 40-47).

PISA. (2015). Sciene Literacy: Average Scores. Diunduh dari: https://nces.ed.gov/surveys/pisa/pisa2015/ pisa2015highlights 3.asp. tanggal 1 Maret 2018

Rusman. (2010). Model-Model pembelajaran: Mengembangkan Profesionalisme Guru. Jakarta: Raja Grafindo Persada.

Sari, A. N., Harahap, N. (2016). Pengaruh Model Pembelajaran Berbasis Masalah (Problem Based Learning) Terhadap Hasil Belajar dan Keterampilan Proses Sains Siswa pada Materi Sistem Reproduksi Manusia di Kelas X1-PMS SMA Negeri 1 Binjai Tahun Pembelajaran 2014/2015. Jurnal Pelita Pendidikan, 3(4), 29-39.

Umar, M. A. (2017). Penerapan Pendekatan Saintifik dengan Metode Pembelajaran Berbasis Proyek (Project-Based Learning) dalam Materi Ekologi. Jurnal BIOnatural, 4(2), 1-12.

Wahyudi, A., Marjono, dan Harlita. (2015). Pengaruh Problem Based Learning Terhadap Keterampilan Proses Sains dan Hasil Belajar Biologi Siswa Kelas X SMA Negeri Jumapolo Tahun Pelajaran 2013/2014. BIO-PEDAGOGI, $4(1), 5-11$.

Widayati, T. U., Prayitno, B. A., dan Ariyanto, J. (2015). Perbedaan Kemampuan Memecahkan Masalah dan Retensi Menggunakan Model PBL (Problem Based Learning) dan Ceramah Bervariasi pada Materi Keanekaragaman Hayati Indonesia Siswa Kelas X MIA SMA Negeri 2 Surakarta Tahun Pelajaran 2014/2015. Bio-Pedagogi, 4(1), 53-58.

Yennita, R. M., Yasin, Z. H., Ikhsan, dan Osman, K. (2015). Pelakasanaan Pembelajaran Berbasis Proyek Dalam Sains di Kota Pekanbaru. Jurnal Pendidikan, 4(2), 79-85. 